\title{
Heavy metals pollution in sediment cores from the Gulf of Aqaba, Red Sea
}

\author{
Tariq Al-Najjar ${ }^{1^{\star}}$, Mohamad Rasheed ${ }^{2}$, Zaid Ababneh $^{3}$, Anas Ababneh $^{3}$, Hosam Al-Omarey $^{3}$ \\ ${ }^{1}$ Faculty of Marine Sciences, Department of Marine Biology, Jordan University, Aqaba Branch, Aqaba, Jordan; \\ *Correspondence Author: t.najjar@ju.edu.jo \\ ${ }^{2}$ Marine Science Station, Aqaba, Jordan; \\ ${ }^{3}$ Physics Department, Yarmouk University, Irbid, Jordan.
}

Received 9 August 2011; revised 11 September 2011; accepted 25 September 2011.

\begin{abstract}
The distribution of metals $(\mathrm{Cd}, \mathrm{Cr}, \mathrm{Pb}, \mathrm{Cu}, \mathrm{Ni}$ and $\mathrm{Zn}$ ) was determined in sediment cores collected from five major areas representing different anthropogenic activities along the Jordanian coast during 27 February-11 March 2008. Metal concentrations in these sediments were relatively low compared to reported values from polluted areas. At some of the sites metal concentrations showed fluctuations with depth in the core suggesting changes in metal loading with time. The calculated contamination factors (CFs) for the suite of metals decreased in the following order $\mathrm{Cd}>\mathrm{Pb}>\mathrm{Cr}>\mathrm{Ni}>\mathrm{Zn}>\mathrm{Cu}$. The Pollution Loading Index (PLI) calculated for the different areas were highest at Phosphate Loading Berth $(0.008,0.2607,0.0161,0.007,47.9375$ and 0.0296 for $\mathrm{Cu}, \mathrm{Pb}, \mathrm{Ni}, \mathrm{Zn}, \mathrm{Cd}$ and $\mathrm{Cr}$, respectively) and lowest at Hotel Area (0.0001, 0.0075, 0.0008, $0.0006,1.0483$ and 0.0005 for $\mathrm{Cu}, \mathrm{Pb}, \mathrm{Ni}, \mathrm{Zn}, \mathrm{Cd}$ and $\mathrm{Cr}$, respectively) with others sites between these extremes. Result of this study could be used to assess the magnitude of pollution at each site and guide rational management decisions. Moreover, the data constitutes a baseline against which future anthropogenic effects can be assessed.
\end{abstract}

Keywords: Metals; Core sediments; Pollution Loading Index; Contamination Factor; Gulf of Aqaba; Red Sea

\section{INTRODUCTION}

Within rapid industrialization and economic development in coastal areas around the world heavy metals are introduced to the coastal environment [1,2]. Studies have been curried to evaluate heavy metal distribution in sur- face sediments to assess the degree of pollution in the marine environment $[3,4]$. Heavy metals are transported as either dissolve species in water or in association with suspended sediments and are subsequently deposited and stored in bottom sediments. After burial some the distribution of some redox sensitive metal could be modified by natural processes in the sediment. The bioaccumulation of heavy metals in coastal sediments can be hazardous to the local population which uses the coast area for fishing and recreation activities [5,6]. Metal abundance in sediments cores can provide a historical record of changes in metal contamination over time and their relation to historical changes in land use and anthropogenic activity [7,8]. Specifically, if the sediment core is intact and sediments remain undisturbed by human activities or extensive bioturbation then a continuous record over time could be obtained [6,9]. Most of the previous studies, dealing with levels of heavy metal pollution in the coastal areas along the Jordanian coast focused on relating heavy metals in surface sediments to those seen in living organisms such as algae and seagrass [10], sea urchin [11] and sea cucumber [12]. The objective of this work is to study the concentration of six metals nickel $(\mathrm{Ni})$, copper $(\mathrm{Cu})$, lead $(\mathrm{Pb})$, zinc $(\mathrm{Zn})$, cadmium $(\mathrm{Cd})$ and chromium $(\mathrm{Cr})$ in sediment cores collected at 3 water depths $(5,15$ and $35 \mathrm{~m})$ at five sites characterized by various industrial and tourism activities along the Jordanian coast of the Gulf of Aqaba. These data will provide a historical record of spatial and temporal changes in metal pollution. To quantify the magnitude of pollution two measures were employed: Contamination Factor (CF) and Pollution Load Index (PLI).

\section{METHODS}

\subsection{Study Area}

The Gulf of Aqaba is the north eastern segment of the Red Sea. It is located between $28^{\circ}-29^{\circ} 30^{\prime} \mathrm{N}$ and $34^{\circ} 30^{\prime}$ - 
$35^{\circ} \mathrm{E}$ [13] (Figure 1). The Gulf is deep (max. depth 1800 $\mathrm{m}$ ) and narrow (180 km long, $14-26 \mathrm{~km}$ wide) and is surrounded by desert mountains with negligible inputs of fresh water or run-off. This area has a hot and dry climate with average temperature of $23^{\circ} \mathrm{C}$. The sea surface temperature ranges between $21^{\circ} \mathrm{C}$ during winter and $27^{\circ} \mathrm{C}$ during summer with temperatures of $21^{\circ} \mathrm{C}$ even in deep waters. The net evaporation in this area is $0.5-1$ $\mathrm{cm} \cdot \mathrm{day}^{-1}[13]$. The study area lies within the Jordanian portion of the Gulf of Aqaba, located at the most northern and northeastern side of the Gulf and extended about $27 \mathrm{~km} \mathrm{[14].} \mathrm{The} \mathrm{coastal} \mathrm{areas} \mathrm{on} \mathrm{the} \mathrm{Gulf} \mathrm{are} \mathrm{im-}$ portant environmental, economical, and recreational areas in Jordan.

\subsection{Sample Collection and Treatment}

Sediments were collected by scuba diving at five coastal locations along the Jordanian coast (Hotels Area (HA), Phosphate Loading Berth (PLB), Marine Science Station (MSS), Tala Bay (TB) and Industrial Area (IA)) (Figure 1). Cores were all obtained within a short time interval between the 27th of February and 11th of March 2008. The selected locations represent the different types and extend of anthropogenic activities occurring along the Jordanian coast. Specifically the Hotels Area lies on the beach of city of Aqaba and is impacted by a high density of visitors; the Phosphate Loading Berth (PLB) is situated about $3 \mathrm{~km}$ south of Aqaba city and it is the port used for loading and export of phosphate from Jordan; the Marine Science Station (MSS) is located $10 \mathrm{~km}$ south of Aqaba city close to the passengers port where ferry traffic arrives from Egypt, the MSS sites is known for its wide variety benthic habitants and excellent back reef lagoon; Tala Bay Marina (TB) lies about $14 \mathrm{~km}$ south of the city of Aqaba, it is an integrated residential and tourist resort; the Industrial Area (IA) site is located 15 $\mathrm{km}$ south of the main port of Aqaba, at this location several plants for fertilizer and phosphate ore production and handling as well as storage and loading facilities. Sediment cores were collected at three different water column depths $(5 \mathrm{~m}, 15 \mathrm{~m}$ and $35 \mathrm{~m})$ at each location using a sharp stainless steel core of $8 \mathrm{~cm}$ in diameter. Each core was about $15 \mathrm{~cm}$ long and was sectioned in the laboratory into three sections $(0-5 \mathrm{~cm}, 5-10 \mathrm{~cm}$ and 10 - $15 \mathrm{~cm}$ ). Sediment samples were dried until a constant weight was obtained, after that samples were homogenized and kept in Naylon bags. A subsample (100 g) was used for grain size analysis using standard dry sieving and sedimentation techniques [15].

\subsection{Heavy Metal Analysis}

For heavy metal analysis $0.2 \mathrm{~g}$ of the homogenized sediment was dried at $105^{\circ} \mathrm{C}$, placed in pre-cleaned 100 $\mathrm{ml}$ glass beakers, and $8 \mathrm{ml}$ of $69.5 \%$ ultra-pure nitric acid was added to each beaker. Samples were left to react at room temperature for $4 \mathrm{hrs}$. Beakers were then put on a hot plate at $100^{\circ} \mathrm{C}$ for $6 \mathrm{hrs}$, allowed to cool to room temperature and heated again to near dryness in order to remove the nitric acid. The residue was dissolved in $8 \mathrm{ml}$ of $1 \%$ nitric acid and kept on a hot plate for about $1 \mathrm{hr}$ to

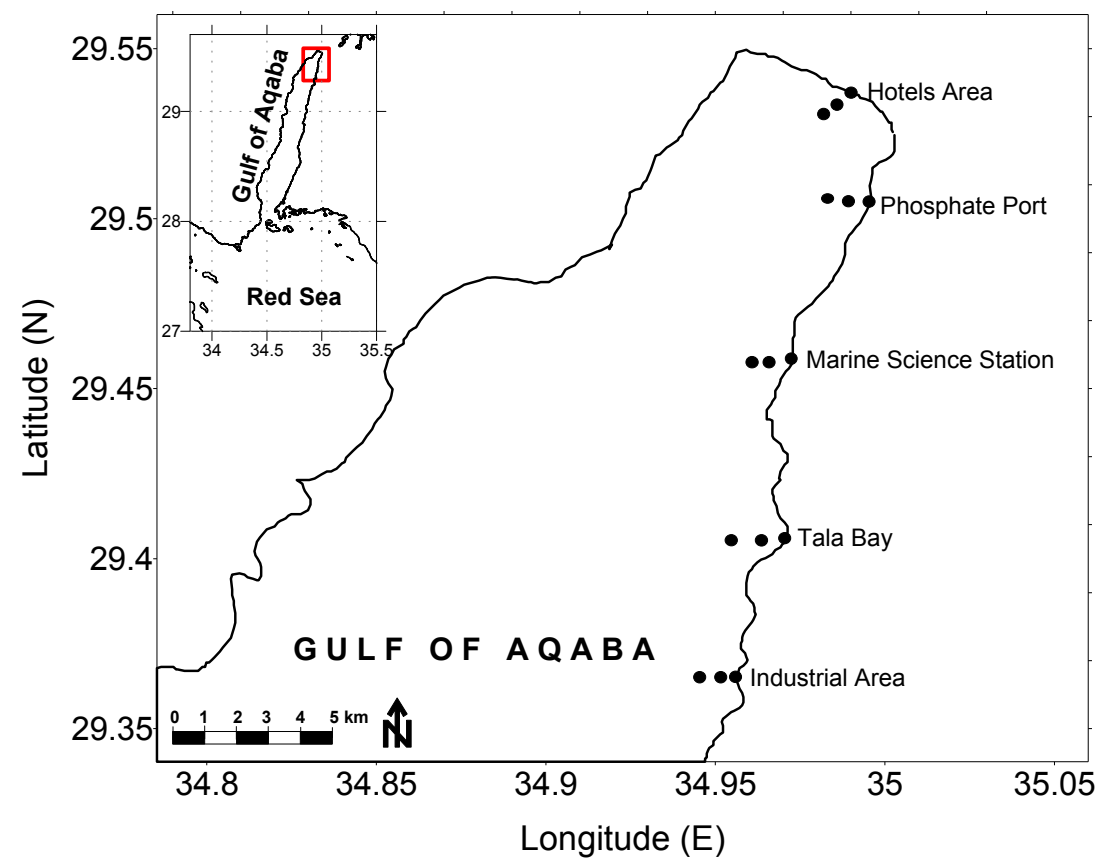

Figure 1. Sampling sites at the northern Gulf of Aqaba, Red Sea. 
enhance dissolution. The samples were allowed to cool to room temperature and then filtered on a Whatman filter paper number 43 . Samples were finally diluted to $25 \mathrm{ml}$ with $1 \%$ nitric acid. Concentrations of $\mathrm{Cd}, \mathrm{Cr}, \mathrm{Ni}$, $\mathrm{Pb}, \mathrm{Cu}$ and $\mathrm{Zn}$ were measured on a Jena AA 400 atomic absorption spectrophotometer by direct aspiration into air-acetylene flame. The instrument was programmed to report the mean value and standard deviations of three repeat analyses of each sample. The precision of the whole procedure was assessed by 10 replicates for a sample and the results agreed to within 3\%. Duplicate blanks were prepared and analyzed with each batch of digested samples. The mean value of the blank was subtracted from the readings of the sample to give the final reading. Three standard solutions that expected range of the element concentrations in the samples were also prepared and analyzed along with the samples. The standard calibration curves were linear. The final element concentrations are reported in $\mu \mathrm{g} \cdot \mathrm{g}^{-1}$ unit.

\section{RESULTS AND DISCUSSION}

\subsection{Sediment Type}

The texture and chemical properties of the sediment at the different sites were quite different. Sediments from the northernmost locations were fine, black and oxygen deficient, whereas sediments from the southern locations were white, better oxygenated, and slightly coarser [16]. Table 1 shows the sediment type at the various sampling locations. The sediment texture is sandy at MSS, TB and
IA indicating of the high energetic regime of alongshore currents allowing the washout the finer particles [6,17]; the hotel area has sandy silt sediments and the sediments are PLB are dominated by clays. The fine sediments at PBL are a result of substantial amounts of phosphate powder deposited at the site from dust ore blowing during the process of shipment. This site also has a higher sedimentation rate compared to the other sites along the Jordan coast [16].

\subsection{Trends in Element Concentrations in the Sediment Cores}

The heavy metals concentration profiles obtained from the collected cores are shown in Figure 2. Different elements exhibited different trends in their vertical distribution at the different sites.

For Chromium (Cr), at most sites the highest detected concentrations were recorded in the interval between 10 $15 \mathrm{~cm}$. However, PLB Cr profiles showed an additional peak at $5-10 \mathrm{~cm}$. Analytical results obtained by [18,19] indicated that $\mathrm{Cr}$ as $\left(\mathrm{Cr}^{6+}\right)$ is relatively mobile and migrate to the reduced zone which is typically present at the deeper levels in our cores. Indeed this may explain the presence of a $\mathrm{Cr}$ peak at the deepest interval where oxygen is most depleted and the presence of a peak at shallower depth at PLB where sedimentation rates are highest and thus oxygen penetration is retarded. Nickel (Ni), which is quite abundant in the Earth's crust, enters surface waters from the dissolution of rocks and soil, from biological sources, atmospheric fallout, and especially

Table 1. Depth, date, location color, type and organic matter content in sediments at each of the sampling sites.

\begin{tabular}{|c|c|c|c|c|c|c|}
\hline Site & Depth (m) & Date & Latitude & Longitude & Color & Type \\
\hline MS & 5 & 7 Mar 2008 & $29^{\circ} 27^{\prime} 555^{\prime \prime} \mathrm{N}$ & $34^{\circ} 58^{\prime} 435^{\prime \prime} \mathrm{E}$ & Brown to Gray & Sandy \\
\hline MS & 15 & 4 Mar 2008 & $29^{\circ} 27^{\prime} 555^{\prime \prime} \mathrm{N}$ & $34^{\circ} 58^{\prime} 435^{\prime \prime} \mathrm{E}$ & Brown to Gray & Sandy \\
\hline MS & 35 & 7 Mar 2008 & $29^{\circ} 27^{\prime} 555^{\prime \prime} \mathrm{N}$ & $34^{\circ} 58^{\prime} 435^{\prime \prime} \mathrm{E}$ & Brown to Gray & Sandy \\
\hline HA & 5 & 27 Feb 2008 & $29^{\circ} 27^{\prime} 986^{\prime \prime} \mathrm{N}$ & $34^{\circ} 59^{\prime} 532^{\prime \prime} \mathrm{E}$ & Black & Sandy Silt \\
\hline HA & 15 & 4 Mar 2008 & $29^{\circ} 27^{\prime} 986^{\prime \prime} \mathrm{N}$ & $34^{\circ} 59^{\prime} 532^{\prime \prime} \mathrm{E}$ & Black & Sandy Silt \\
\hline HA & 35 & 4 Mar 2008 & $29^{\circ} 27^{\prime} 986^{\prime \prime} \mathrm{N}$ & $34^{\circ} 59^{\prime} 532^{\prime \prime} \mathrm{E}$ & Black & Sandy Silt \\
\hline IA & 5 & 12 Mar 2008 & $29^{\circ} 22^{\prime} 705^{\prime \prime} \mathrm{N}$ & $34^{\circ} 57^{\prime} 602^{\prime \prime} \mathrm{E}$ & White & Sandy \\
\hline IA & 15 & 12 Mar 2008 & $29^{\circ} 22^{\prime} 705^{\prime \prime} \mathrm{N}$ & $34^{\circ} 57^{\prime} 602^{\prime \prime} \mathrm{E}$ & White & Sandy \\
\hline IA & 35 & 12 Mar 2008 & $29^{\circ} 22^{\prime} 705^{\prime \prime} \mathrm{N}$ & $34^{\circ} 57^{\prime} 602^{\prime \prime} \mathrm{E}$ & White & Sandy \\
\hline $\mathrm{PL}$ & 5 & 10 Mar 2008 & $29^{\circ} 30^{\prime} 191^{\prime \prime} \mathrm{N}$ & $34^{\circ} 59^{\prime} 465^{\prime \prime} \mathrm{E}$ & Gray to Black & Clay \\
\hline $\mathrm{PL}$ & 15 & 10 Mar 2008 & $29^{\circ} 30^{\prime} 191^{\prime \prime} \mathrm{N}$ & $34^{\circ} 59^{\prime} 465^{\prime \prime} \mathrm{E}$ & Gray to Black & Clay \\
\hline $\mathrm{PL}$ & 35 & 10 Mar 2008 & $29^{\circ} 30^{\prime} 191^{\prime \prime} \mathrm{N}$ & $34^{\circ} 59^{\prime} 465^{\prime \prime} \mathrm{E}$ & Gray to Black & Clay \\
\hline $\mathrm{TB}$ & 5 & 11 Mar 2008 & $29^{\circ} 26^{\prime} 386^{\prime \prime} \mathrm{N}$ & $34^{\circ} 58^{\prime} 148^{\prime \prime} \mathrm{E}$ & Brown to Gray & Sandy \\
\hline TB & 15 & 11 Mar 2008 & $29^{\circ} 26^{\prime} 386^{\prime \prime} \mathrm{N}$ & $34^{\circ} 58^{\prime} 148^{\prime \prime} \mathrm{E}$ & Brown to Gray & Sandy \\
\hline TB & 35 & 11 Mar 2008 & $29^{\circ} 26^{\prime} 386^{\prime \prime} \mathrm{N}$ & $34^{\circ} 58^{\prime} 148^{\prime \prime} \mathrm{E}$ & Brown to Gray & Sandy \\
\hline
\end{tabular}


778

T. Al-Najjar et al. / Natural Science 3 (2011) 775-782
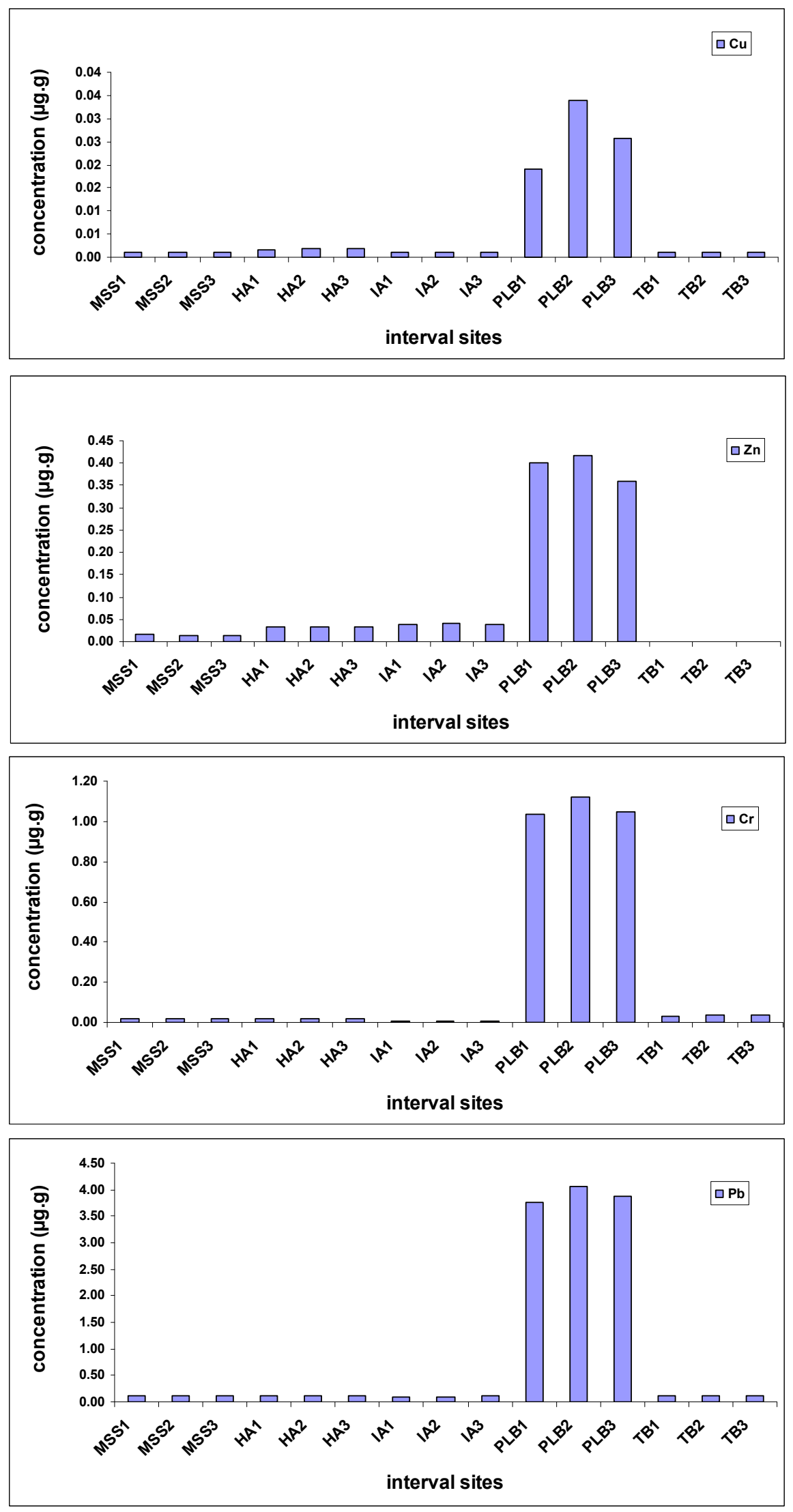

Copyright (C) 2011 SciRes.

OPEN ACCESS 

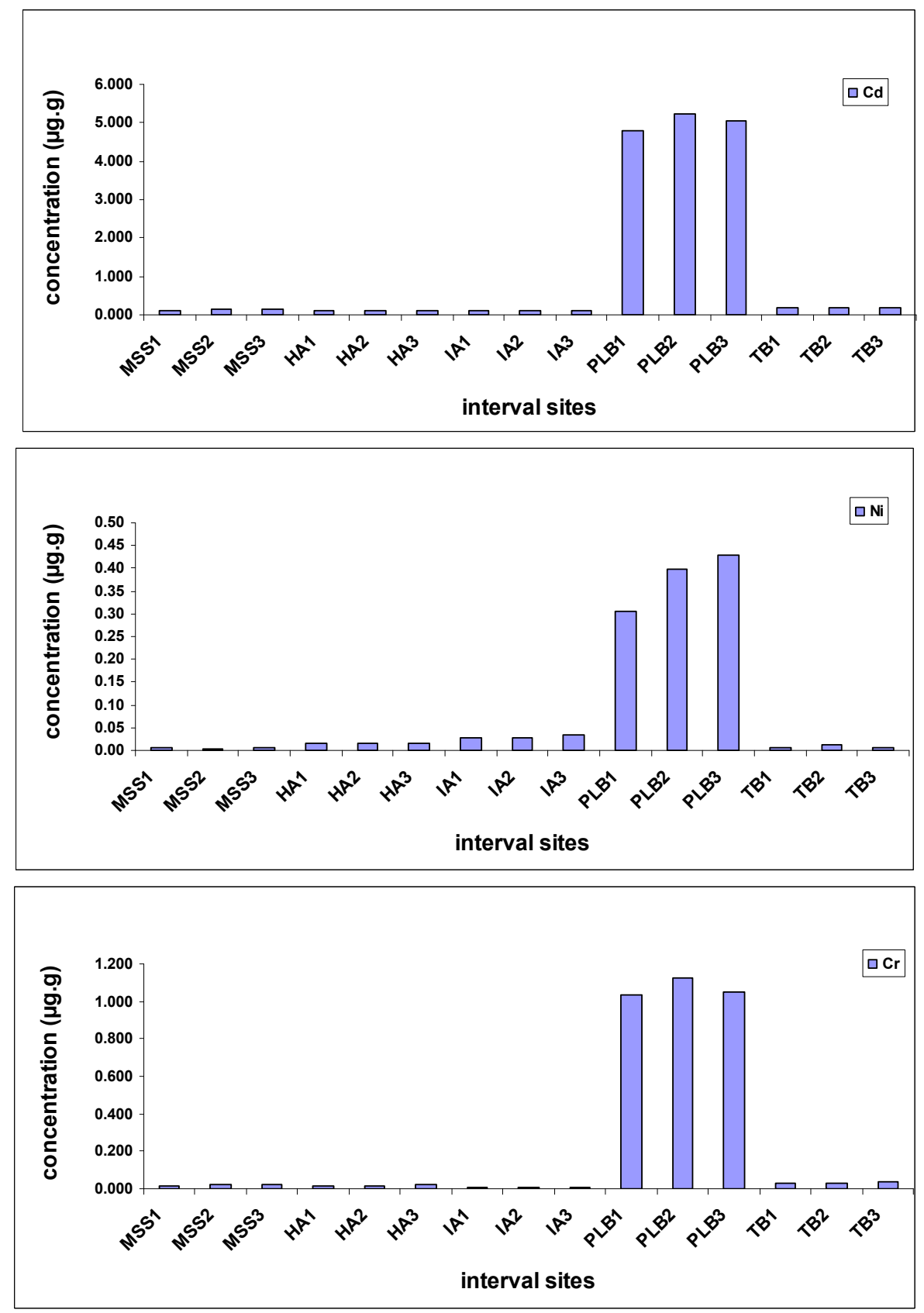

Figure 2. Mean metal concentration $\left(\mu \mathrm{g} \cdot \mathrm{g}^{-1}\right)$ at all sampling site.

from industrial processes and waste disposal [20]. The vertical distribution of $\mathrm{Ni}$ exhibited a distinct in- crease in concentrations in the $10-15 \mathrm{~cm}$ section at both PLB and IA and similar profiles with somewhat lower concentrations at other sites. According to [21], the increase of Ni content at subsurface layers is due to Ni sorption onto manganese oxyhydroxides. It is well known that $\mathrm{Ni}$ is insoluble at the $\mathrm{pH}$ values of marine en- vironment ( $>6.7)$ and exist predominantly as $\mathrm{Ni}$ hydroxides [22] which is turn are quickly incorporated into particles. Copper $(\mathrm{Cu})$, is one of the most common contaminants associated with urban runoff. Important anthropogenic inputs of $\mathrm{Cu}$ in estuarine and coastal waters include sewage sludge dump sites, municipal waste discharge, and antifouling paints [23]. In relatively clean sediments, $\mathrm{Cu}$ concentrations are about $50 \mu \mathrm{g} \cdot \mathrm{g}^{-1}$ while sediments with concentration of $>60 \mu \mathrm{g} \cdot \mathrm{g}^{-1}$ are classified by the EPA as contaminated [24]. According to the cal- culated overall average concentration of $\mathrm{Cu}\left(0.03 \mu \mathrm{g} \cdot \mathrm{g}^{-1}\right)$ in the five studied sites the sediments studied are uncontaminated with respect to $\mathrm{Cu}$. The vertical profiles of $\mathrm{Cu}$ in the studied cores showed similar patterns of distribution at 
all sites. At PLB slightly higher concentration at $5-15$ $\mathrm{cm}\left(0.034 \mu \mathrm{g} \cdot \mathrm{g}^{-1}\right)$ was recorded but the difference between this concentration and those recorded at other sites is not statistically significant. Zinc ( $\mathrm{Zn})$ is a naturally abundant element present as a common contaminant in agricultural food wastes, manufacturing of pesticides as well as in antifouling paints. The vertical distribution pattern of $\mathrm{Zn}$ was similar to that of $\mathrm{Cr}$. Down core profiles of $\mathrm{Zn}$ suggest no changes in $\mathrm{Zn}$ pollution over time in this region as also recognized by [25]. However, at PLB a maximum in $\mathrm{Zn}$ was found in the $5-10 \mathrm{~cm}$ interval $\left(0.42 \mu \mathrm{g} \cdot \mathrm{g}^{-1}\right)$ with lower values above and below. This finding might be attributed to the upward migration of $\mathrm{Zn}$ during organic matter degradation [25] or possibly to a period with higher $\mathrm{Zn}$ pollution at this site. Cadmium (Cd) which is a transition element behaves in the environment as a cumulative toxin [24]. It is listed by EPA as one of 129 priority pollutants and among the 25 most hazardous substances. Moreover, there is an international agreement forbidding discharge of any $\mathrm{Cd}$ into the sea [26]. It has been suggested that natural sources of Cd contribute $10 \%-30 \%$ through windblown transport of soil particles and volcanic emissions [23]. The main source of $\mathrm{Cd}$ to the marine environment is mainly anthropogenic through atmospheric loading of refining and use of $\mathrm{Cd}$ [23]. The vertical distribution pattern of $\mathrm{Cd}$ in our cores showed an increase of its content with increasing depth in the core. Higher $\mathrm{Cd}$ contents in the PLB core $\left(4.79-5.23 \mu \mathrm{g} \cdot \mathrm{g}^{-1}\right)$ compared to the concentrations at other sites of this study (0.098 - 0.187 $\left.\mu \mathrm{g} \cdot \mathrm{g}^{-1}\right)$ is consistent with the higher metal contamination at this site. It is well recognized that $\mathrm{Cd}$ is sensitive to redox changes; it is soluble in oxygenated conditions and precipitates immediately where reducing conditions are encountered [27]. Lead $(\mathrm{Pb})$ compounds are also potentially harmful, especially tetraethyl lead [28]. It is listed by EPA as a carcinogen material. Concentrations of $\mathrm{Pb}$ in the studied sediments like $\mathrm{Cd}$ and $\mathrm{Zn}$ show low concentrations $\left(0.1-0.123 \mu \mathrm{g} \cdot \mathrm{g}^{-1}\right)$ with slightly higher values of $\mathrm{Pb}$ in PLB core, The maximum value of $\left(4.07 \mu \mathrm{g} \cdot \mathrm{g}^{-1}\right)$ was obtained in the $5-10 \mathrm{~cm}$, interval and the minimum value was in the $0-5 \mathrm{~cm}$ section. High $\mathrm{Pb}$ concentrations are attributed to several sources such as boat exhausted systems, spillage of oil and other petroleum compounds form mechanized boats employed for fishing [29,30], all of these sources are present in the study area. In addition to these sources, atmospheric input of $\mathrm{Pb}$ generated from automobile exhaust emission can contribute a significant amount of $\mathrm{Pb}$ at PLB area which is located at the main port area where intensive traffic activities exists.

\subsection{Estimating Pollution Impacts}

A number of methods have been put forward for quantifying the degree of metal enrichment in sediments. Va- rious authors $[2,6,31,32]$ have proposed pollution impact scales or ranges to convert the numerical concentration results into broad groups of pollution ranges (e.g. low to high intensity). A contamination factor [33] is defined as the metal concentration in sediment divided by some background base value for each element. The background value corresponds to the baseline concentrations reported by [34] and is based on element abundances in sedimentary rocks (shale) (Table 2). The ranges used to describe the contamination factor are: $\mathrm{CF}<1$ is considered as low contaminated; $1<\mathrm{CF}<3$ is moderate contamination; $3<\mathrm{CF}<6$ is considerable contamination and $\mathrm{CF}>6$ is high contaminations.

The $\mathrm{CF}$ values for the various metals are shown in Table 3. The metal CF levels at all sample sites are present in the following order $\mathrm{Cd}>\mathrm{Pb}>\mathrm{Cr}>\mathrm{Ni}>\mathrm{Zn}>\mathrm{Cu}$. Cadmium concentration are relatively high in the study area, the CF ranged between $1-1.8$ suggesting low to moderate contamination in all stations except at PLB where the $\mathrm{CF}$ value indicates extreme contamination (CF $=48$ ). Low contamination factor was observed for $\mathrm{Pb}, \mathrm{Cr}$, $\mathrm{Ni}, \mathrm{Zn}$ and $\mathrm{Cu}$ at all stations.

We also computed the pollution loading index (PLI) for our samples according to [33] using the following equation:

$$
P L I=\left(C F_{1} \times C F_{2} \times C F_{3} \times \cdots \times C F_{n}\right)^{\left(\frac{1}{n}\right)}
$$

where: $P L I=$ pollution loading index; $C F=$ contamination factor; $n=$ number of metals investigated.

The $P L I$ was calculated for the five areas under investigation using the six investigated metals $(\mathrm{Cd}, \mathrm{Pb}, \mathrm{Ni}$, $\mathrm{Cu}, \mathrm{Zn}$ and $\mathrm{Cr}$ ). It was observed that the highest $P L I$ was found at PLB (0.06), while the lowest was calculated for Tala Bay (0.001), the calculated $P L I$ were found in the following sequences: PLB $>$ HA $>$ IA $>$ MSS $>$ TB. The PLI values computed in our study are much lower than those reported [6], for the Red Sea (7.5 - 5.6; Table 4) and may indicate that the specific region we studied is less polluted.

\section{CONCLUSIONS}

Our results represent the first study on metals in core sediments of Jordanian coastal areas of the Gulf of Aqaba, Red Sea. The data indicate that the sediments at most of our sampling sites are uncontaminated. The only site with significant contamination particularly for $\mathrm{Cd}$ was found at the PLB site likely due to the extensive industrial activity at this site. The calculated $\mathrm{CFs}$ were found in the following order $\mathrm{Cd}>\mathrm{Pb}>\mathrm{Cr}>\mathrm{Ni}>\mathrm{Zn}>$ $\mathrm{Cu}$. The pollution Loading Index (PLI) calculated for different areas were found in the following sequences: 
Table 2. Metal concentrations $\left(\mu \mathrm{g} \cdot \mathrm{g}^{-1}\right)$ in average continental crust used for calculating $P L I$ [34].

\begin{tabular}{cccc}
\hline Elements & Average continental crust & Elements & Average continental crust \\
\hline $\mathrm{Cr}$ & 35 & $\mathrm{~Pb}$ & 14.8 \\
$\mathrm{Cu}$ & 25 & $\mathrm{Zn}$ & 52 \\
$\mathrm{Ni}$ & 19 & $\mathrm{Cd}$ & 0.1 \\
\hline
\end{tabular}

Table 3. Contamination Factors for surface sediments.

\begin{tabular}{ccccccc}
\hline Area & $\mathrm{Cu}$ & $\mathrm{Pb}$ & $\mathrm{Ni}$ & $\mathrm{Zn}$ & $\mathrm{Cd}$ & $\mathrm{Cr}$ \\
\hline MSS & 0.0001 & 0.0077 & 0.0003 & 0.0003 & 1.2617 & 0.0005 \\
HA & 0.0001 & 0.0075 & 0.0008 & 0.0006 & 1.0483 & 0.0005 \\
IA & 0.0001 & 0.0070 & 0.0015 & 0.0008 & 0.9550 & 0.0002 \\
PLB & 0.0008 & 0.2607 & 0.0161 & 0.0077 & 47.9375 & 0.0296 \\
TB & 0.0001 & 0.0084 & 0.0003 & 0.0000 & 1.7600 & 0.0009 \\
\hline
\end{tabular}

Table 4. Concentrations of metals $\left(\mu \mathrm{g} \cdot \mathrm{g}^{-1}\right)$ in surface sediments worldwide compared to those in the present study.

\begin{tabular}{|c|c|c|c|c|c|c|c|}
\hline Location & $\mathrm{Cu}$ & $\mathrm{Pb}$ & $\mathrm{Ni}$ & $\mathrm{Zn}$ & $\mathrm{Cd}$ & $\mathrm{Cr}$ & Reference \\
\hline Gulf of Aqab & 0.03 & 4.07 & 0.43 & 0.42 & 5.25 & 1.12 & Present study \\
\hline Red Sea, KSA & 25.76 & 92.86 & 90.79 & 93.86 & 3.95 & 35.36 & {$[6]$} \\
\hline Red Sea, Egypt & 21.43 & & & 51.4 & & & {$[35]$} \\
\hline Al-Hodeidah, Yemen & 11.3 & 3.48 & 13.25 & 30 & 14.2 & 20.2 & {$[36]$} \\
\hline Aegean Sea & 9.6 & 22.3 & 38.4 & 75 & 0.25 & 35.7 & [37] \\
\hline Gulf of Mannar & 57 & 16 & 24 & 73 & 0.16 & 177 & {$[28]$} \\
\hline South East Coast-India & 506.21 & 32.36 & 38.61 & 126.83 & 6.58 & 194.83 & [2] \\
\hline Gulf of Mannar & 57 & 16 & 24 & 73 & 0.16 & 177 & {$[38]$} \\
\hline
\end{tabular}

$\mathrm{PLB}>\mathrm{HA}>\mathrm{IA}>\mathrm{MSS}>\mathrm{TB}$. The results of this study could be used as a baseline against which future anthropogenic effects can be assessed and for management decision to reduce pollution particularly at the PLB site.

\section{ACKNOWLEDGEMENTS}

We acknowledge the effort of the Marine Science Station in support this research. We thank Dean of scientific research, Yarmouk University for their support. Our work was supported by the NATO projects (SfP 982161 and 981883).

\section{REFERENCES}

[1] Santos, I.R., Silva-Filho, C.E., Schaefer, C.E., Albuquerque-Filho, M.R. and Campos, L.S. (2005) Heavy metals contamination in coastal sediments and soil near the Brazilian Antarctic Station, King George Island. Marine Pollution Bulletin, 50, 185-194.

doi:10.1016/j.marpolbul.2004.10.009

[2] Muthu, R.S. and Jayaprakash, M. (2008) Distribution and enrichment of trace metals in marine sediments of Bay of Bengal, off Ennore, South-east coast of India. Environmental Geology, 56, 207-217. doi:10.1007/s00254-007-1156-1
[3] Pekey, H. (2006) The distribution and source of heavy metals in Izmit Bay surface sediments affected by pollution stream. Marine Pollution Bulletin, 52, 1197-1208. doi:10.1016/j.marpolbul.2006.02.012

[4] Bellucci, L.G., Frignani, M., Paolucci, D and Ravanekki, M. (2002) Distribution of heavy metals in sediments of the Venice lagoon the role of industrial area. Science of the Total Environment, 295, 35-49. doi:10.1016/S0048-9697(02)00040-2

[5] El-Rayis, O.A., Aboul-Dahab, O.M., Halim, Y. and Riley, J.P. (1997) Concentrations and distribution of heavy metals in bottom sediments of El-Mex may (Alexandria), prior to construction of El-Dekhaila Quays. 3rd Conference of Geochemistry, Alexandria, 3-4 September 1997, 169-173.

[6] Badr, N.B.E., El-Fiky, A.A., Mostafa, A.R. and Al-Mur, B.A. (2009) Metal pollution records in core sediments of some Red Sea coastal areas, Kingdom of Saudi Arabia. Environ Monitor Assessment, 155, 509-526. doi:10.1007/s10661-008-0452-x

[7] Winkels, H.J., Vink, J.P.M. and Beurskens, J.E.M. (1993) Distribution and geochronology of priority pollutants in a large sedimentation area, River Rhine, Netherland. $A p$ plied Geochemistry, S2, 95-101. doi:10.1016/S0883-2927(09)80018-8

[8] Buckley, D.E., Smith, J.N. and Winters, G.V. (1995) Ac- 
cumulation of contaminants metals in marine sediments of Halifax Harbour, Nova Scotia: Environmental factors and historical trends. Applied Geochemistry, 10, 175-195. doi:10.1016/0883-2927(94)00053-9

[9] Lo, C.K. and Fung, Y.S. (1992) Recovery of heavy metals from acid digestion of an estuarine sediment and concentration profiles of sediment cores from Hebe Haven and Ngua Mei Hoi, Hong Kong. International Journal of Environmental analytical chemistry, 46, 277-291. doi:10.1080/03067319208032568

[10] Abu-Karma, Y.M. (2006) Algae and seagrass as Bioindicators for trace metals pollution along the Jordanian coast of the Gulf of Aqaba. MSc Thesis, Yarmouk University, Irbid, Jordan.

[11] Tawaha, M. (2006) Sea Urchen Diadema setosum as possible bioindicator for trace metal pollution in the Gulf of Aqaba, Red Sea. MSc Thesis, Yarmouk University, Irbid, Jordan.

[12] Alshabi, M.O. (2010) Sea cucumber as possible bioindicator for trace metal pollution in the Gulf of Aqaba, Red Sea. MSc Thesis, Yarmouk University, Irbid, Jordan.

[13] Manasrah, R.S., Al-Horani. F.A., Rasheed. M.Y., AlRousan S.A. and Khalaf, M.A. (2006) Pattern of summer vertical and horizontal currents in coastal waters of the northern Gulf of Aqaba, Red Sea. Estuarine, Coastal and Shelf Science, 69, 567-579. doi:10.1016/j.ecss.2006.05.024

[14] Abu-Hilal, A.H. and Al-Najjar, T.H. (2004) Litter pollution on the Jordanian shores of the Gulf of Aqaba. Marine Environmental Research, 58, 39-63. doi:10.1016/j.marenvres.2003.12.003

[15] Krumbein, W.C. and Petttijijohn, F.J. (1938) Manual of sedimentary petrology, Appleton, Century and Crofts, New York, 549

[16] Badran, M.I. and Al-Zibdah, M.K. (2005) Environmental quality of Jordan coastal surface sediment, Gulf of Aqaba, Red Sea. Royal Swedish Acaemy of Sciences, 34, 615620.

[17] Gheith, A.M. and Abu-Ouf, M.A. (1996) Texture characteristics, mineralogy and fauna in the shore zone sediments at Rabigh and Sharm al-kharrar, East Red Sea, Saudi Arabia. Marine Science, 7 (Special Issue: Symposium on Red Sea Marine Environment. Jeddah 1994).

[18] Gaillard, J.F., Pauwells, H. and Michard, G. (1989) Chemical digenesis of coastal marine sediments. Oceanologica Acta, 12, 175-187.

[19] Janaki-Raman, D.M.P., Jonathan S.S., Armstrong-Altrin, J.S., Mohan, S.P. and Rama-Mohan, V. (2007) Trace metal enrichments in core sediments in Muthupet mangroves, SE Coast of India: Application of acid leachable technique. Environmental pollution, 145, 245-257. doi:10.1016/i.envpol.2006.03.012

[20] Prego, R., Belzunce Segarra, M.J., Helios-Rybicka, E. and Barciela, M.C. (1999) Cadmium, manganese, nickel and lead contents in surface sediments of the lower Ulla River and its estuary (Northwest Spain). Bulletin de IInstitut Oceanographique. Institute Oceanographique, 15, 495-500.

[21] Zwolsman, J., Van Eck, G. and Burger, G. (1996) Spatial and temporal distribution of trace metals in sediment from the Scheldt Estuary, South-West Netherlands. Estuarine. Coastal and Shelf Science, 43, 55-79. doi:10.1006/ecss.1996.0057

[22] Sunderman, W.F.Jr. and Oskarsson, A. (1991) Nickel. In: Merian, E., Ed., Metals and Their Compounds in the Environment, $\mathrm{VCH}$, Weinheim, 1101-1126.

[23] Kennish, M.J. (1996) Practical handbook of estuarine and marine pollution, CRC, Boca Raton, 524.

[24] Ingersoll, C.G. and Nelson, M.K. (1989) Testing sediment toxicity with Hayallella azteca (Amphipoda) and Chironomus riparius (Diptera). ASTM STP 13th Symposium of Aquatic Toxicity Risk Assessment, Atlanta, 16-18 April 1989, 43.

[25] Rubio, B., Pye, K., Rae, J.E. and Rey, D. (2001) Sedimentological characteristics, heavy metal distribution and magnetic properties in subtidal sediments, Ria de Pontevedra, NW Spain. Sedimentology, 48, 1277-1296.

[26] Clark, R.B., Frid, C. and Attril, M. (1997) Marine pollution. Oxford University Press, New York, 161.

[27] Thomson, J., Nixon, S., Croudace, I.W., Pedersen, T.F., Brown, L., Cook, G.T., et al. (2001). Redox-sensitive elements uptake in Northeast Atlantic Ocean sediments (Benthic Boundary Layer Experiment Site). Earth and Planetary Science Letter, 184, 535-547.

[28] Jonathan, M.V. and Mohan, V.R. (2003) Heavy metals in sediments of the inner shelf off the Gulf of Mannar, South East Coast of India. Marine Pollution Bulletin, 46, 258268.

[29] Abu-Hilal, A.H. (1987) Distribution of trace elements in near shore surface sediments from the Jordan Gulf of Aqaba (Red Sea). Marine Pollution Bulletin, 18, 190-193.

[30] Laxen, D.P.H. (1983) The chemistry of metal pollution in water. In: Horrison, R.M., Ed., Pollution Causes, Effects and Control, The Royal Society of Chemistry, WIVOBN, London, 104.

[31] Salomons, W. and Forstner, U. (1984) Metals in hydrocycle. Springer, Berlin, 63-98.

[32] Hokanson, L. (1980) Ecological risk index for Aquatic pollution control, a sedimentological approach. Water Research, 14, 975-1001.

[33] Tomlinson, D.L., Wilson, J.G., Harris, C.R. and Jeffrey, D.W. (1980) Problems in the assessment of heavy metal levels in estuaries and the formation of a pollution index. Helgoland Marine Research, 33, 566-575.

[34] Wedepohl, K.H. (1995) The composition of the continental crust. Geochimica et Cosmocheim Acta, 59, 1217 1232.

[35] Okbah, M.A., Shata, M.A. and Shraidah, M.A. (2005) Geochemical forms of trace metals in mangroves sediment, Red Sea, Egypt. Chemistry and Ecology, 21, 23-36.

[36] Al-adrise, M.A.M. (2002) Concentration of some heavy metals in Kour-Kutheb Area (Al-Hodiedah) as a result of the sewage effluent impact. MSc Thesis, Hodeida University, Hodeida.

[37] Esin, E., Kucuksezgin, F. and Uluturhan, E. (2008) Assessment of trace metal pollution in surface sediments of Nemrut bay, Aegean Sea. Environmental Monitoring and Assessment, 160, 257-266. 